\title{
VIOLÊNCIA, OPRESSÃO E RESISTÊNCIA: VIOLAÇÃO DOS DIREITOS FUNDAMENTAIS DAS MULHERES INDÍGENAS NO BRASIL
}

\section{CLARISSA CALAIS GUIMARÃES}

Graduanda em Direito, modalidade integral, pela Escola Superior Dom Helder Câmara. Belo Horizonte-MG. E-mail: clacalaisolv@gmail.com

\section{CAIO AUGUSTO SOUZA LARA}

Mestre e Doutor em Direito pela Faculdade de Direito da Universidade Federal de Minas Gerais - UFMG. Professor da Escola Superior Dom Helder Câmara. Pesquisador Associado ao Programa RECAJ-UFMG - Acesso à Justiça e Solução de Conflitos. Secretário de Comunicação do Conselho Nacional de Pesquisa e Pósgraduação em Direito - CONPEDI. Belo Horizonte-MG. E-mail: caiolarabh@yahoo.com.br

\section{RESUMO}

O tema-problema da pesquisa que se pretende desenvolver é a questão da violação dos direitos fundamentais das mulheres indígenas. Nesse sentido, embora o relativismo cultural defenda que o bem e o mal, o certo e o errado, entre outras categorias de valores, são relativos a cada cultura, ou seja, o "bem" coincide com o que é "socialmente aprovado" em um determinado espaço e tempo, existe um freio ao relativismo absoluto das culturas, que é a lei. Pode-se entender que existem culturas diferentes no mundo, mas não se pode defender a violência contra a mulher. A tolerância termina na lei, a violência esbarra na lei, e ambas constituem o campo do ilegal. Logo, quando as pessoas dizem que o relativismo aceita tudo, se equivocam. O discurso de que "naquela cultura a mulher está acostumada a apanhar", e por isso 


\section{Personalidade Acadêmica Homenageada:}

\section{Raymundo Juliano Feitosa (Universidade Federal do Rio Grande do Norte - UFRN)}

o conceito de defesa da mulher não é valido, não pode ser aceito. Sendo assim, nenhuma distinção pode ser feita a partir da égide da defesa da dignidade da pessoa humana; dentro dessa conjuntura, essas premissas colocam fim ao relativismo. É imprescindível ressaltar, que ideias e opiniões são livres, desde que não infrinjam a lei. Nesse âmbito, as mulheres indígenas sofrem preconceito duas vezes, primeiro por serem indígenas, e depois por serem mulheres. A luta, no geral é para que sejam garantidos, o respeito e a dignidade, além do lugar que lhes foi usurpado desde a colonização na sociedade brasileira. O problema objeto da investigação científica proposta é: quais são os principais direitos fundamentais das mulheres indígenas que são violados? A partir das reflexões preliminares sobre o tema, é possível afirmar inicialmente, que o direito à vida é, em primeiro lugar, o mais violado, devido a limpeza étnica e aos assassinatos por pistoleiros como forma de intimidar o povo a deixar as aldeias. Ademais, a não garantia do direito à igualdade e a estar livre de todas as formas de discriminação, o não ou o escasso acesso à saúde, e a submissão à torturas e maus-tratos, representam contravenções contínuas dos direitos das mulheres. O objetivo geral do trabalho é analisar a questão da violência contra as mulheres indígenas, verificar quais são os direitos fundamentais das mulheres que são violados dentro desse contexto, bem como examinar a questão da discriminação e da marginalização dessas pessoas, e constatar a não aplicabilidade e a não adequação das leis de proteção à mulher indígena. A pesquisa que se propõe pertence à vertente metodológica jurídico-sociológica. No tocante ao tipo de investigação, foi escolhido o tipo jurídico-projetivo. O raciocínio desenvolvido na pesquisa será predominantemente dialético. De acordo com a técnica de análise de conteúdo, afirma-se que se trata de uma pesquisa teórica, o que será possível a partir da análise de conteúdo dos textos doutrinários, normas e demais dados colhidos na pesquisa. A partir do exposto, conclui-se que as discussões sobre a violação dos direitos fundamentais das mulheres indígenas são cada vez mais relevantes, principalmente no que tange à tentativa de garantir que haja a adequação das leis de proteção à mulher, às diferentes realidades vivenciadas por essa parcela da população, com respeito às suas respectivas particularidades culturais e sociohistóricas. Para tanto, é de extrema importância o reconhecimento da necessidade de 
Personalidade Acadêmica Homenageada:

Raymundo Juliano Feitosa (Universidade Federal do Rio Grande do Norte - UFRN)

tutela jurídica para com essas mulheres, fato este que se torna ainda mais evidente diante dos constantes episódios de violação, em diversos sentidos, desde os direitos mais básicos, que são, em tese, assegurados não somente pela Constituição Federal de 1988, mas também por todos os acordos assinados pelo Brasil, no que diz respeito a proteção íntegra de sua população.

PALAVRAS-CHAVE: Violação de direitos; Mulheres; Indígenas.

\section{REFERÊNCIAS}

BRASIL. Constituição da República Federativa do Brasil de 1988. Disponível em: http://www.planalto.gov.br/ccivil_03/constituicao/constituicao.htm. Acesso em: 30 abr. 2019.

FONSECA, Lívia Gimenes Dias da. A construção intercultural do direito das mulheres indígenas a uma vida sem violência: a experiência brasileira. Hendu, v. 06, p. 69-87, 2015.

FUNAI. Mulheres Indígenas participam de Encontro Nacional a Proteção e Promoção dos seus Direitos. 19 nov. Disponível em: http://www.funai.gov.br/index.php/comunicacao/noticias/2223-mulheresindigenasparticipam-de-encontro-nacional-a-protecao-e-promocao-dos-seus-direitos. Acesso em 07 abr 2019.

GUSTIN, Miracy Barbosa de Sousa; DIAS, Maria Tereza Fonseca. (Re)pensando a Pesquisa Jurídica. 4. ed. Belo Horizonte: Del Rey, 2015.

PEDROSA, Clara Cristina Cruz; MONT'AVÃO Victória Diamantino Ferreira. A "Novas Fronteiras do Feminismo: O Feminismo Indígena" Revista Jurídica - UNICURITIBA, $\begin{array}{llllll}\text { Curitiba, } & \text { v.1 } & \text { n.20, } & \text { p. } 75 \quad \text { - } & \text { 81, } 2017 . \quad \text { Disponível }\end{array}$ em: http://revista.unicuritiba.edu.br/index.php/percurso/article/view/2436/1459.

Acesso em: 20 mai. 2019.

SILVA, Paulo Pitaluga Costa e. A alma do índio. In: Antologia Indígena. Mato Grosso: INBRAPI, 2005. p. 8-11.

VERDUM, Ricardo (Org.). Mulheres Indígenas, Direitos e Políticas Públicas. Brasília: Inesc, 2008.

WITKER, Jorge. Como elaborar uma tesis en derecho: pautas metodológicas y técnicas para el estudiante o investigador del derecho. Madrid: Civitas, 1985. 